\title{
SOME REFLECTIONS ON THE EXTRATERRITORIAL APPLICATION OF THE EUROPEAN CONVENTION ON HUMAN RIGHTS
}

\author{
DobrostaWA C. BUDZIANOWSKA*
}

\begin{abstract}
INTRODUCTION
The European Convention on Human Rights (ECHR) entered into force in 1953. Since then, art. 1 of the Convention has regulated its jurisdiction. It states that "the High Contracting Parties shall secure to everyone within their jurisdiction the rights and freedoms defined in (...) this Convention." However, no definition of the term 'jurisdiction' is provided in art. 1 nor in any of the other articles of the Convention. The European Court of Human Rights (ECtHR) generally upholds a strictly territorial notion of jurisdiction in its jurisprudence. The lack of codification and clear rules in this regard results in disagreement between writers as to the scope and role of the extraterritorial application of the ECHR. Some argue that it is of a general nature $^{1}$, whereas others claim that the ECHR applies extraterritorially in precisely prescribed scenarios only ${ }^{2}$. In the course of this paper the instances where the ECHR has been applied extraterritorially will be examined. It will be demonstrated that these precedents are well-established in the ECtHR's jurisprudence and constitute a clear yet flexible legal framework for applying the Convention extraterritorially. It shall be further shown that the Court uses the notion of protection of human rights to develop extraterritorial jurisdiction. It will then be supposed that the ECtHR will continue to build its jurisprudence on the subject within the already-established framework. It will be demonstrated that this framework is narrow and applicable only in a limited number of scenarios, with national opposition being one of the reasons for this limitation.
\end{abstract}

DOI: $10.2478 /$ wrlae-2013-0021

* LL.B. (University of London), LL.M. (Université Paris I Panthéon-Sorbonne), Ph.D. Candidate at the Chair of International and European Law, University of Wroclaw; email: dobroslawa.budzianowska@prawo.uni.wroc.pl.

${ }^{1}$ Tarik Abdel-Monem, 'How Far Do the Lawless Areas of Europe Extend? Extraterritorial Application of the European Convention on Human Rights' (2005) 14 Journal of Transnational Law \& Policy 159.

${ }^{2}$ Sarah Miller, 'Revisiting Extraterritorial Jurisdiction: A Territorial Justification for Extraterritorial Jurisdiction under the European Convention' (2010) 20 European Journal of International Law 1223. 


\section{THE MEANING OF 'JURISDICTION' UNDER GENERAL INTERNATIONAL LAW}

The ECHR is a multilateral international treaty and the ECtHR uses the principles of general public international law when interpreting its provisions. This practice applies to the term 'jurisdiction' ${ }^{3}$. Under international law, "jurisdiction is an aspect of sovereignty and refers to judicial, legislative and administrative competence." 4

As the territorial principle is interrelated with the principle of state sovereignty ${ }^{5}$, "the first and foremost restriction imposed by international law upon a State is that (...) it may not exercise its power in any form in the territory of another state." 6 The rule was restated and confirmed in a UK decision dealing with the issue of overlapping jurisdictions of more than one state over a given territory. The court held that in normal circumstances jurisdiction cannot be exercised by one state over the territory of another ${ }^{7}$. Hence, under international law jurisdiction is essentially territorial.

What is more, there is no applicable rule of general international law, provided either in treaties or legal writings, that would prescribe a particular meaning to 'jurisdiction' of states under human rights treaties. The general prohibition on imposing jurisdiction over another state's territory is not an absolute one as "restrictions upon the independence of states cannot be presumed." 8 This accords states discretion in applying their laws extraterritorially". The International Court of Justice has held that "while the jurisdiction of States is primarily territorial, it may sometimes be exercised outside the national territory." 10 Indeed, there are cases where states have used this discretion, regardless of potential protests from other states. For instance, courts in the United States have developed a practice of solving jurisdictional conflicts by employing the 'balancing of interests' approach. This approach involves an examination of the interests of the US and those of other states in applying the laws in question. Using this approach, the courts held that US law was lawfully applied extraterritorially in the Timberlane and Mannington Mills cases ${ }^{11}$. Such an understanding of jurisdiction may lead to unprincipled assertions of jurisdiction, as demonstrated by the US Military

\footnotetext{
${ }^{3}$ Clare Ovey and Robin White (eds), Jacobs \& White: The European Convention on Human Rights, (4th edn, Oxford University Press 2006) 25.

${ }^{4}$ Ian Brownlie, Principles of Public International Law, (7th edn, Oxford University Press 2008) 299.

${ }^{5}$ Vaughan Lowe, 'Jurisdiction' in Malcolm D Evans (ed), International Law (2nd edn, Oxford University Press 2006) 342.

${ }^{6}$ S.S. Lotus Case (France v Turkey) PCIJ Rep Series A No. 10 (1927) 18.

${ }^{7}$ Unreported case before Essex Assizes, summarized in UKMIL (1978) 49 BYIL 393.

${ }^{8}$ S.S. Lotus Case (n 6) 18.

${ }^{9}$ Lowe (n 5) 341.

${ }^{10}$ Legal Consequences of the Construction of a Wall In the Occupied Palestinian Territory, Advisory Opinion [2004] ICJ Rep 136, para. 109.

${ }^{11}$ Discussed in Hartford Fire Insurance Co v California (1993) 113 S Ct 2891, and Andreas F Lowenfeld, 'Conflict, Balancing of Interests, and the Exercise of Jurisdiction to Prescribe: Reflections on the Insurance Antitrust Case' (1995) 89 American Journal of International Law 42.
} 
Order of 13 November $2001^{12}$. The Order concerned individuals suspected of terrorism held at the US military base in Guantanamo Bay, Cuba, and prohibited them from seeking redress at any court or tribunal, be it a court of the US or another state. The US disregarded the views of other states on the matter, according more importance to its own interests. In effect, the order allowed for a lawful depravation of human rights, and clearly illustrates the dangers of an unduly lax approach to 'jurisdiction'.

Moreover, the meaning of 'jurisdiction' under human rights treaties is a source of lively debate among writers. Some point to similarities between the ECHR and the International Covenant on Civil and Political Rights (ICCPR) 1966. It is now accepted that the ICCPR may apply extraterritorially ${ }^{13}$. This does not, however, support the argument that the ECHR should be applied extraterritorially as well. The provisions of the ICCPR regarding the jurisdictional scope of the Covenant are different from those of the Convention in that they are wider ${ }^{14}$. Under the Vienna Convention on the Law of Treaties 1969 (VCLT), both conventions are required to be interpreted in accordance with their strict wording. The interpretation leads to different conclusions regarding the meaning of 'jurisdiction' in each of the Conventions. Article 2(1) of the ICCPR mentions 'territory' as well as 'jurisdiction', whereas the ECHR focuses only on 'jurisdiction'.

\section{THE MEANING OF 'JURISDICTION' UNDER THE ECHR}

The jurisdiction of a legal instrument can be determined using various principles: the nationality principle, the passive nationality principle, the protective or security principle, the universality principle, and the aforementioned territorial principle ${ }^{15}$. In every scenario, one of them will take precedent over the others, and the most basic one is the territorial principle. The ECtHR follows international law, and thus the criterion of territoriality is typically applied to determine 'jurisdiction' under the ECHR. The Court has departed from this practice and acknowledged that the ECHR applies extraterritorially only in exceptional cases.

The ECtHR is bound to interpret the 'jurisdiction' of states under the ECHR according to the VCLT ${ }^{16}$. Under art. 31(1) VCLT, the interpretation of a norm must take into account not only the wording used, but also the context, object and purpose of the treaty. The travaux preparatoires to the ECHR provide such a context and they do not support the notion of

\footnotetext{
${ }^{12}$ Available at: www.whitehouse.gov/news/releases/2011/11/print/20111113-27.html.

${ }^{13}$ Legal Consequences of the Construction of a Wall In the Occupied Palestinian Territory (n 10) 136, para. 109.

${ }^{14}$ Marko Milanovic, Extraterritorial Application of Human Rights Treaties: Law, Principles, and Policy, (Oxford University Press 2011) 11.

${ }^{15}$ Lowe (n 5) 335-358.

${ }^{16}$ Heribert Golsong, 'Interpreting the European Convention on Human Rights beyond the Confines of the Vienna Convention on the Law of Treaties?' in Ronald St John Macdonald, Franz Matscher and Herbert Petzold (eds), The European System for the Protection of Human Rights (Martinus Nijhoff 1993) 147.
} 
extraterritorial application of the Convention. The travaux preparatoires clearly present jurisdiction in the territorial sense ${ }^{17}$, especially given the provisions of the 'colonial' clause in article 56 of the ECHR ${ }^{18}$. Under art. 32 VCLT, recourse to preparatory work on a treaty is a subsidiary means for interpretation. Therefore, to establish a case for the meaning and interpretation of the ECHR it is more helpful to refer back to the purpose of the Convention. Under art. 1 the purpose of the ECHR is to secure and promote human rights within the State Parties' territories. Excluding the possibility of extraterritorial application of the Convention when such an application is not prohibited by international law would go against this purpose. Hence, art. 1 of the Convention must not be understood as absolutely limiting the obligations of Contracting Parties solely to their sovereign territory.

Indeed, in one of the most authoritative cases on the subject of extraterritorial application of the ECHR, Loizidou v. Turkey, the ECtHR established that "although art. 1 sets limits on the reach of the Convention, the concept of 'jurisdiction' under this provision is not restricted to the national territory of the High Contracting Parties." 19 Admittedly, in its later judgment in Ilascu v. Moldova and Russia, the Court remarked that "the words 'within their jurisdiction' in art. 1 of the Convention must be understood to mean that a State's jurisdictional competence is primarily territorial (...), that the jurisdiction is presumed to be exercised normally throughout the State's territory." ${ }^{20}$ Nonetheless, the use of the words 'primarily' and 'normally' indicate that this is not an absolute rule. Thus, the ECtHR did not close itself off from the possibility of applying the Convention extraterritorially. The Court has provided further guidance and a framework for construing art. 1 of the ECHR in its case law, to which attention will now turn.

\section{ECTHR WIDENS THE SCOPE OF INTERPRETATION OF 'JURISDICTION'}

There has been controversy over the exact meaning of 'jurisdiction' under the Convention, namely whether it should be understood as 'authority' ${ }^{21}$ or as 'power' 22 . The dichotomy can be explained as the choice between the interpretation of jurisdiction as the fact of possessing 'judicial, legislative and administrative' authority over the territory in question, and the fact of possessing the power to take 'judicial, legislative and administrative' actions within the territory. The ECtHR has established that jurisdiction can be understood both as power and authority ${ }^{23}$.

\footnotetext{
17 Traveaux Preparatoires de l'article ler de la Convention europeenne des Droits de l'Homme, 'Obligation to Respect Human Rights', Cour (77)9.

18 Traveaux Preparatoires de l'article 63 de la Convention europeenne des Droits de l'Homme, 'Territorial Application', Cour (78)8.

${ }^{19}$ Loizidou v Turkey (Preliminary Objections) (1995) 20 EHRR 99, para. 62; recalled in Loizidou v. Turkey (Merits) (1996) 23 EHRR 513, para. 52.

${ }^{20}$ Ilascu v Moldova and Russia 40 EHRR 1030, para. 312.

${ }^{21}$ As held in Ilascu (n 20) para. 313.

${ }^{22}$ See ibid, paras. 315-316.

23 ibid, para. 312.
} 


\section{A. Effective Control}

Initially, jurisdiction was understood only as authority. By being interpreted also as power, it came to be assessed in the context of the idea of effective control. The ECtHR concerned itself with the issue of whether a state has the authority to make a decision but also if it has the power to enforce it. Such power, corresponding to the notion of effective control, indicates whether the state is able to secure the human rights of the individuals on the territory under its control. Possessing effective control over a territory thus typically gives rise to jurisdiction. Nonetheless, it has not always been clear what role effective control has in establishing state responsibility. ${ }^{24}$ The Court has stated that "a State's responsibility may be engaged where (...) it in practice exercises effective control of an area situated outside its national territory." ${ }^{25}$ This rule applies to cases of occupation when authority is imposed by alien forces possessing effective control $^{26}$.

The possibility of establishing jurisdiction through finding of effective control widens the potential for extraterritorial application of the ECHR. The test for establishing effective control is subjective and takes into account the position of a state on whose national territory the effective control is exercised. The ECtHR stated that the original state, if it is a State Party, which might have lost effective control over a part of its territory will be under "a duty to take all the appropriate measures which it is still in its power to take" in order to secure the Convention rights ${ }^{27}$.

The threshold of the effective control test is high. The most restrictive view on when effective control is exercised was adopted by the ECtHR in the Bankovic decision ${ }^{28}$. The post-Bankovic case law is more lax. In Assanidze v. Georgia $^{29}$ the applicant complained of actions carried out by the Ajarian Autonomus Republic, a part of Georgia enjoying autonomous status. The Ajarian authorities failed to comply with the decisions of the central government, giving rise to the application to the ECtHR. The Court held that the central government exercised effective control over the whole of Georgian territory despite its inability to secure compliance with its decisions. The Georgian government thus possessed jurisdiction over the state in the meaning of art. 1 ECHR.

The ECtHR jurisprudence provides further guidance on the exercise of extraterritorial control which qualifies as effective control for the purposes of establishing jurisdiction. In the case of occupation, jurisdiction shifts from the original state to that exercising effective control. In Cyprus v. Turkey effective occupation of the northern part of Cyprus was sufficient to establish the jurisdiction of Turkey. Furthermore, military occupation of Germany by

\footnotetext{
${ }^{24}$ Recently, the issue was considered in Behrami and Behrami v France and Saramati $v$ France, Germany and Norway 45 EHRR (2007) 10, where the Grand Chamber discussed the 'effective control' test alongside the 'ultimate authority' test.

${ }^{25} \mathrm{Ilascu}$ (n 20), para. 314.

${ }^{26}$ Hague Convention IV Respecting the Laws and Customs of War on Land, signed on 18 October 1907, Annex, Article 42; Adam Roberts, 'What Is a Military Occupation' (1984) 55 British Yearbook of International Law 249, 251. See for example Cyprus v Turkey (2001) 35 EHRR 731.

${ }^{27}$ Ilascu (n 20), para. 331.

${ }^{28}$ Bankovic and others $v$ Belgium and 16 other Contracting States (2002) 6 EHRLR 775.

${ }^{29}$ Assanidze v Georgia (2004) 39 EHRR 653, para. 139.
} 
Soviet forces absolved Germany from liability for the Soviets' acts ${ }^{30}$, whereas in Ilascu Moldova was found not to exercise authority over a part of its territory and the liability shifted to the occupying Russian authorities due to their support for the created 'Republic of Transdniestria'. However, in Assanidze the inability of the central government to fully exercise its power over a part of the territory was insufficient to absolve Georgia of responsibility as a lack of administrative power is not equal to a lack of effective jurisdiction. Lastly, in Bankovic the NATO member states were held not to be liable for human rights violations occurring as a result of aerial bombings by NATO. The ECtHR applied a very restrictive interpretation of 'effective control' and used the public international law interpretation of 'jurisdiction'. As a result, it did not apply extraterritorially in this case. The same reasoning and standards of the jurisdiction and control tests were applied in Cyprus v. Turkey. This line of jurisprudence is clearly too restrictive. The Court limited itself to black letter law principles, not attaching enough weight to the purpose and spirit of the Convention. Fortunately it has not been, and hopefully will not be, followed in the later case law.

\section{B. Extraterritorial Exercise of Authority}

The purely territorial notion of jurisdiction under the ECHR remains a general rule. The exceptions laid out in $\mathrm{Ilascu}^{31}$ and reiterated in Assanidze include "acts of public authority performed abroad by diplomatic and consular representatives of the State; the criminal activities of individuals overseas against the interests of the State or its nationals; acts performed on board vessels flying the State flag or on aircraft or spacecraft registered there; and particularly serious international crimes (universal jurisdiction)." 32 In cases where such an exercise of authority is established, the Convention would apply extraterritorially.

Another exception to the territorial construction of jurisdiction was provided in Cyprus v. Turkey. Under this exception, "the acquiescence or connivance of the authorities of a Contracting State in the acts of private individuals which violate the Convention rights of other individuals within its jurisdiction may engage the State's responsibility under the Convention."33 This means that states can be found to have violated the Convention rights by allowing private individuals to violate the rights of other individuals. This will primarily apply in the cases of "recognition by the State in question of the acts of self-proclaimed authorities which are not recognised by the international community." 34 Hence, any independent movement having its origin on the territory of a State Party and proclaiming authority over any territory can cause that state to be liable for breaches of Convention rights committed by that movement. If the authority is exercised outside the State Party's territory, it will trigger extraterritorial application of the Convention and extraterritorial liability of that State Party.

\footnotetext{
${ }^{30}$ Von Maltzan and others, von Zitzewitz and others, and Man Ferrostaal and Topfer Stiftung $v$ Germany (2006) 42 EHRR 92.

${ }^{31} \mathrm{Ilascu}$ (n 20), paras 314-319.

${ }^{32}$ Assanidze v Georgia (n 29), para. 137.

${ }^{33}$ Cyprus v Turkey (n 26), para. 81.

${ }^{34}$ Ilascu (n 20), para. 318.
} 


\section{The Soering Principle}

Furthermore, the Court will somewhat depart from the territoriality principle in cases of extradition, that is to say "acts which have sufficiently proximate repercussions on rights guaranteed by the Convention, even if those repercussions occur outside its jurisdiction." 35 Therefore, the State Parties to the ECHR are under an obligation to prevent any extraterritorial violations of the Convention rights if it is within their power to do so. The main precedent for this approach is Soering v. United Kingdom ${ }^{36}$, where the Court held that a state is in breach of the ECHR if it extradites a person to a country in which the person's rights guaranteed under the Convention will be breached. Hence, if an extradition is demanded from a State Party by a nonState Party in order to try the individual for a criminal offence and that individual may face the risk of capital punishment on the non-State Party's territory, the State Party cannot lawfully extradite the individual under the ECHR. Otherwise, the state will breach art. 2 and art. 3 of the ECHR, even though the individual in question would be outside the state's territory at the material time. Extradition cases involving a risk of human rights violations thus constitute a separate category of situations where the Convention may apply. However, because they relate to the question of cross-border application of domestic law, they constitute a special category of cases for the purposes of the present discussion. In these cases, the extraterritorial application of the ECHR would not be triggered; the Convention would have an indirect extraterritorial effect instead. The act that can be complained of under the ECHR occurs on a foreign territory where the ECHR has no binding effect, and is caused by a decision or action taken on the territory where the ECHR binds. Extraterritoriality is thus not the central issue in such cases.

\section{Cases of Multiple Responsible States}

In cases where there are multiple states responsible for breaching the Convention rights, such as in Ilascu, the norms of international law apply. The ECtHR will have recourse to the International Law Commission's (ILC) Draft Articles on Responsibility of States for Internationally Wrongful Acts 2001 (Draft Articles). The Draft Articles are a non-binding instrument, however, the customary international law rules expressed in them are binding ${ }^{37}$. Article 47(1) provides that "where several States are responsible for the same internationally wrongful act, the responsibility of each State may be invoked in relation to that act." Hence, any of the states implicated in a violation of the Convention rights can be found to be individually responsible for the breach. This applies to violations committed extraterritorially, and the Convention can be invoked in such cases regardless of the states' resistance. History indicates that only one state can have sufficient degree of control over a territory so as to act as the authority for the population, and to effectively be able to enforce its decisions. From the practical point of view, it is nearly impossible for more than one state to exercise effective control over a given territory at one time, unless they are acting in accord. Arguably, that could

\footnotetext{
35 ibid, para. 317.

${ }^{36}$ Soering v United Kingdom (1989) Series A No. 161, paras. 88-91.

${ }^{37}$ David D Caron, 'The ILC Articles on State Responsibility: The Paradoxical Relationship Between Form and Authority' (2002) 96 American Journal of International Law 857, 872.
} 
only occur in cases of military occupations or actions carried out jointly with all states involved having ultimate control over the military decision-making. Therefore, there was scope for finding multiple states liable in e.g. the Bankovic case. The ECtHR practice indicates that in situations where there are multiple states present on a given territory, only one will typically be found to exercise effective control over it. That was the case in Ilascu, where the ECtHR held only Russia liable for the breach of art. 3 of the Convention. Nonetheless, it is possible that the institution of extraterritorial application of the Convention will be applied in the cases of multiple states involved in a breach of the Convention rights.

\section{E. Vicarious Liability}

As already stated, the ECtHR is bound to apply the norms of general international law. The principles of vicarious liability in international law derive from the norms of customary international law. They are reflected in the Cairo case $^{38}$ and art. 7 of the Draft Articles, and they provide that states will bear the responsibility for ultra vires acts of its agents. Hence, if an agent of a state commits an act breaching a Convention right, that state will be liable for the breach. In the Assanidze decision the Court reaffirmed the rule of vicarious liability by stating that a State Party bears liability for the acts of its agents, such as officials, administrative employees and civil servants. It is irrelevant if the act is committed on the state's territory or on another territory where that state exercises effective control. The principle of vicarious liability under the ECHR law was laid down in Ireland v. United Kingdom ${ }^{39}$. It provides that the ECHR may be applied extraterritorially when the state's "agents are acting ultra vires or contrary to instructions." 40

The rule was applied on an extraterritorial basis in Cyprus v. Turkey ${ }^{41}$, where it was held that a state having control over foreign territory is liable for the acts of its soldiers and officials. More interestingly, Turkey was found to be liable for the acts of local administration and government of the Cypriot territory. The rationale behind this finding was that, by virtue of exercising overall control over the land, Turkey possessed power over the Cypriot political and social fabric. Therefore, if a decision of an official of the occupied state breaches a Convention right, the occupying state can be liable for the breach.

\section{National Perspective}

It has been demonstrated that the ECtHR is rather reluctant to establish extraterritorial jurisdiction of State Parties and adopts a restrictive approach in this regard. It was emphasised by Forowicz that "a more expansive interpretation of this notion may have been met with strong opposition from the Contracting States, given that the Court could be seen as

\footnotetext{
${ }^{38}$ Cairo case, the General Claims Commission (1929) Reports of International Arbitral Awards, 516.

${ }^{39}$ Ireland v United Kingdom (1978) Series A No 25, para. 159.

${ }^{40} \mathrm{Ilascu}$ (n 20), para. 319.

${ }^{41}$ Cyprus v Turkey (n 26), para. 77.
} 
infringing the consensual jurisdiction upon which the ECHR is based."42 This raises the issue of the unwillingness of the ECHR State Parties to be bound by the Convention, as it legally limits and restricts their international military actions. Therefore, it is natural that the UK and other ECHR signatories remain reluctant to the idea of being bound by the ECHR outside their territory.

This unwillingness of states is clear from their resistance to claims brought against their conduct abroad before domestic courts as well as the ECtHR. Recent cases before the UK courts serve as good examples, due to litigation arising out of its military involvement in Iraq and Afghanistan. First, in the Al-Skeini case, the House of Lords held that the ECHR applies on UK territory only ${ }^{43}$. Secondly, in December 2008 the UK failed to comply with an order of the ECtHR aimed at stopping the UK from handing over detainees held in their custody to Iraqi authorities. The UK openly and without precedent violated the ECtHR order. Both cases resulted in actions before the ECtHR, and in both the Court found the ECHR to apply extraterritorially ${ }^{44}$.

It is worth looking at the arguments of the UK in the Al-Saadoon case as to why the ECHR should not apply extraterritorially. The case concerned a transfer by the UK of two men who were in the custody of UK troops in Iraq to Iraqi authorities for trial. As such, it involved the issue of indirect extraterritorial effect. In broad outline, the UK submitted that: (i) the UK did not have jurisdiction over the appellants; (ii) even if it had jurisdiction over the appellants, the obligation not to extradite or transfer the appellants was overridden by the UK's obligation to do so; (iii) there was no relevant regional customary international law in Europe that would prohibit their transfer because of the risk of death penalty; (iv) capital punishment by hanging did not amount to a crime against humanity ${ }^{45}$. These arguments were rejected by the Court, as due to military operations on Iraqi territory the UK was exercising de facto effective control over that territory, which was enough to establish art. 1 jurisdiction.

What is more, the UK Supreme Court found the UK troops stationing in Iraq not to be subject to the Convention rights, effectively depriving their own nationals of protection under the $\mathrm{ECHR}^{46}$. It held that once the soldiers leave the UK camp, they are no longer on the territory under effective control of their state. The court rejected the applicant's claim on the basis that there is no ECtHR precedent regarding the need for inquests into the death of soldiers stationed abroad which would factually support the present claim. The court adopted a conservative approach on the issue of extraterritoriality, relying on a primarily territorial notion of jurisdiction under art. 1 of the Convention. This is even more surprising, as the individual in question was a UK national. Nonetheless, an analogy to cases of effective control exists, and soldiers stationed abroad remain there to act on orders of UK authorities. This

\footnotetext{
${ }^{42}$ Magdalena Forowicz, The Reception of International Law in the European Court of Human Rights (Oxford University Press 2010) 52-53.

${ }^{43}$ Al-Skeini $v$ Secretary of State for Defence [2007] UKHL 26.

${ }^{44}$ Al-Saadoon and Mufdhi v United Kingdom App No. 61498/08 (ECtHR, 30 June 2009); AlSkeini $v$ United Kingdom App No. 55721/07 and Al-Jedda v United Kingdom App No. 27021/08 (ECtHR Grand Chamber, 7 July 2011).

${ }^{45}$ See: ibid.

${ }^{46} R$ (Smith) v Secretary of State for Defence \& Anor [2010] UKSC 29.
} 
is a case that could potentially initiate a new line of precedents where the ECtHR would find the Convention to apply extraterritorially.

\section{CONCLUSIONS}

The ECtHR jurisprudence demonstrates that 'jurisdiction' in art. 1 of the ECHR is not strictly territorial. In its practice the ECtHR gives precedence to the main purpose of the Convention, which is the protection of human rights. Even though art. 1 appears to limit this purpose to State Parties territories only, the State Parties may be held to be in violation of the ECHR even if the acts complained of occur outside their territory. The discussed cases include instances where a state exercises effective control or has authority over a foreign territory, as well as cases of extradition which reflect the idea of indirect extraterritorial effect.

It appears that the ECtHR will continue to uphold the institution of extraterritorial application in its present form. What is more, there is a potential for creation of further exceptions to the territoriality principle of jurisdiction, though given the resistance of the State Parties it will not be a fast process. The resistance of the states to the notion of extraterritorial application of the Convention is natural but is not likely to hinder it. The ECtHR has been quite successful to date in indicating the course of development of standards for human rights protection and it is implausible that in the future it will defer to the opinions of State Parties on the matter.

At present, art. 1 provides a territorial notion of jurisdiction, which may be extended by the ECtHR in exceptional circumstances to other bases of jurisdiction. The ECtHR jurisprudence on the issue of extraterritorial application of the ECHR is well-established and provides stable, though somewhat confusing, guidelines on how extraterritoriality should be understood. The "exceptional circumstances" thus need to be described in more detail by the Court. Nonetheless, it is time for the State Parties to acknowledge the established precedents and give effect to them in their practice. What is more, the ECHR is subject to international law, and if new rules on extraterritorial applications of treaties evolve, the Court will observe them in its judicial decision-making. Thus, it still remains open for the Court to further develop the interpretation of 'jurisdiction' under art. 1 of the Convention, and through this to widen the scope of extraterritorial application of the ECHR. This may happen through elaboration of the existing precedents, but also through the creation of new ones and application of new international law rules on jurisdiction ${ }^{47}$. The scope of circumstances in which the State Parties' jurisdiction under the ECHR is not perceived merely in its territorial sense is established, and although the field may evolve further, it will happen in a measured and restrictive manner.

${ }^{47}$ Cedric Ryngaert, Jurisdiction in International Law, (Oxford University Press 2008) 5. 